\title{
Spatial and temporal trends of sea surface temperature in the northwest African region
}

\author{
Sidina OULD-DEDAH ${ }^{\text {a }}$, William J. WISEMAN Jr. ${ }^{\text {, }}$, Richard F. SHAW ${ }^{\text {* }}$ \\ ${ }^{\text {a }}$ Centre National de Recherches Océanographiques et des Pêches, B.P. 22, Nouadhibou, Mauritanie. \\ ${ }^{\mathrm{b}}$ Coastal Studies Institute, Louisiana State University, Baton Rouge, LA 70803, USA. \\ ${ }^{c}$ Coastal Fisheries Institute, Louisiana State University, Baton Rouge, LA 70803, USA.
}

(Received 2 April 1998, revised 24 November 1998, accepted 26 November 1998)

\begin{abstract}
The timing and structure of sea surface temperature (SST) changes were investigated using data from the continental shelf of the northwest African region and from coastal stations in Mauritania. Fmpirical Orthogonal Function analysis of the data revealed differences between northern regions with permanent upwelling, and southern regions where the upwelling is seasonal. It is then hypothesized that shifts in the onset and duration of upwelling may be occurring. Furthermore, the Mauritanian shelf area, a transition zone between the northern and southern regions, appears to go through a series of cooling and warming trends, which seem to he part of a long-term process affecting the northwest African coast. In this regard, it is shown that there is a strong relationship between SST at $18-20^{\circ} \mathrm{N}$ latitude and the Coastal Upwelling Index computed at a coastal station. This approach may allow for adequate predictions of oceanographic processes over the Mauritanian shelf, and probably the northwest African region, from coastal stations, as has been proven in other upwelling systems such as the California system. (C) Elsevier, Paris / Ifremer / Cnrs / Ird
\end{abstract}

\section{sea surface temperature / upwelling / trends / Mauritania / northwest Africa}

Résumé - Tendences spatiales et temporelles de la température superficielle de l'océan au nord-ouest de l'Afrique. La dynamique spatio-temporelle de la température de surface de la mer est étudiée à partir de données collectées sur le plateau continental de l'Afrique occidentale $\left(10-30^{\circ} \mathrm{N}\right)$. L'analyse par la technique des fonctions orthogonales révèle des différences entre les régions situées au nord du cap Blanc, où l'upwelling est permanent, et celles du sud où l'upwelling est saisonnier. Nous émettons l'hypothèse d'un changement du commencement et de la durée de l'upwelling. De plus, la région mauritanienne, transition entre les deux zones, subit une série de refroidissements et de réchauffements qui paraissent s'intégrer dans un phénomène hydrométéorologique de plus grande ampleur affectant toute la côte nord-ouest africaine. Nous montrons que la température de l'eau à la latitude $18-20^{\circ} \mathrm{N}$ est fortement corrélée à l'indice d'upwelling côtier, calculé à partir d'une station côtière. Cette approche pourrait permettre de prédire des phénomènes océanographiques sur le plateau continental mauritanien et, probablement, sur toute la zone nord-ouest africaine comme elle l'a fait dans d'autres régions d'upwelling telles que la Californie. (C) Elsevier, Paris / Ifremer / Cnrs / Ird

température superficielle / upwelling / tendance / Mauritanie / Afrique du Nord-Ouest

\section{INTRODUCTION}

The northwest African ecosystem, like many other eastern boundary current systems (Peru, California, South Africa) is known to be among the most productive sys- tems in the world due to a number of oceanographic processes, in particular upwelling $[5,10,15,20,23,26,34$, 44]. Off Mauritania, this productivity seems to be additionally enhanced by such factors as topography (e.g. wider shelf area off Cap Blanc, numerous capes and

* Correspondence and reprints 
canyons) and the characteristics of water masses around this area (e.g. North and South Atlantic Central Waters: NACW and SACW). Description of the northwest African ecosystem variability has been, in general, inferred from atmospheric pressure and wind field data [15, 24, 38]. Rarely are studies based on in situ measurements. Recently some attempts to describe the system using satellite imagery produced interesting results $[9,16,27,40]$. Yet, most of these studies remain rather limited in space and time.

The objective of this paper is to explore the structure and timing of the seasonal cycle of sea surface temperature (SST) along the northwest African coast using measurements on the shelf (1946-1988) as well as from coastal stations (1960-1988). The main focus is to characterize spatial and/or temporal trends in SST. Particular emphasis is given to the Mauritanian shelf which, because of its transitional nature, carries signals (such as changes in the upwelling regime) that could reflect conditions over the whole northwest African continental shelf. In the last section, we will focus our attention on possible links between coastal stations in Mauritania and oceanographic processes at larger scales.

\section{MATERIAL AND METHODS}

Long-term trends as well as large scale features in SST were investigated using the Comprehensive Ocean Atmosphere Data Set (COADS, [45]). These data consist of monthly SST measurements made around the shipping lanes in the Atlantic that are averaged in $2^{\circ} \times 2^{\circ}$ squares (figure 1). More than one million observations were collected over a 43 year period (1946-1988) in the study area which extends from $10^{\circ} \mathrm{N}$ to $30^{\circ} \mathrm{N}$. Empirical Orthogonal Function (EOF) analysis of the data set was conducted using PRINCOMP [35]. EOF is a multivariate technique useful for data and trend reduction which enables highly correlated variables to be reduced to a small number of orthogonal functions [18, 33]. This reduction technique is frequently applied to oceanographic and meteorological data $[7,19,36,39,41,42]$.
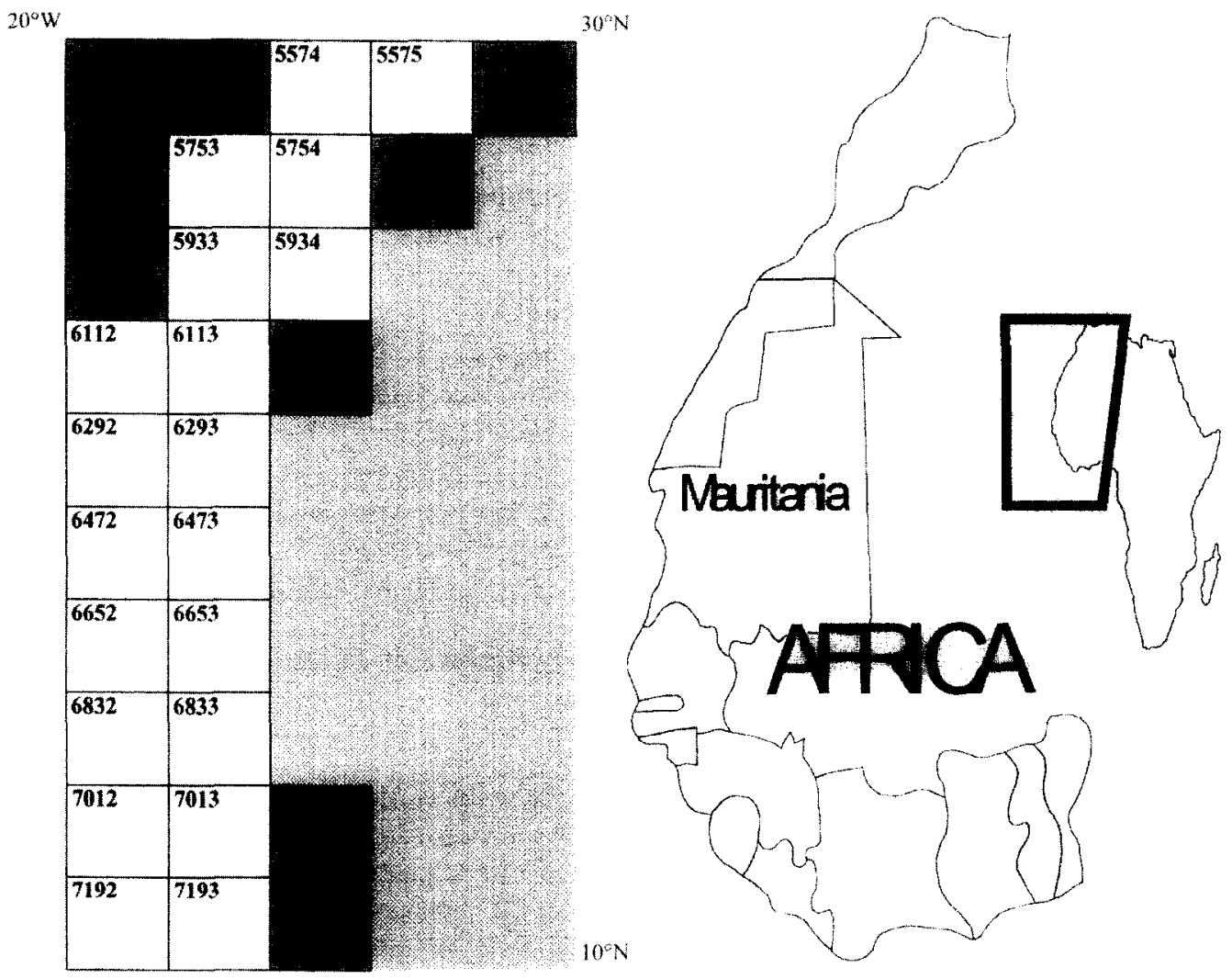

Figure 1. The study area with the $2^{\circ} \times 2^{\circ}$ Marsden squares (map from Harvard Graphics). 
At smaller spatial scales $\left(20^{\prime} \times 20^{\prime}\right.$ squares $)$, the data used were mainly extracted from the database of the National Center for Fisheries and Oceanography (Centre National de Recherches Océanographiques et des Pêches or CNROP), Nouadhibou, Mauritania (figure 2). This database consists of measurements made during scientific expeditions as well as from scientific observations on board the fishing flect off the Mauritanian coast [12].
Additional data were obtained from the National Oceanographic Data Ccnter (NODC), Washington, D.C., USA and the U.S. National Oceanic and Atmospheric Administration (NOAA).

These finer-scale data were analysed to characterize the short, seasonal SST cycle in the Mauritanian EEZ (19831993). The shelf was then partitioned into two areas,
Figure 2. Geographic location of the $20^{\prime} \times 20$ squares. Also noted are the nothern and southern zones of the Economic Exclusive Zone on either side of the $19^{\circ} \mathrm{N}$ latitude.

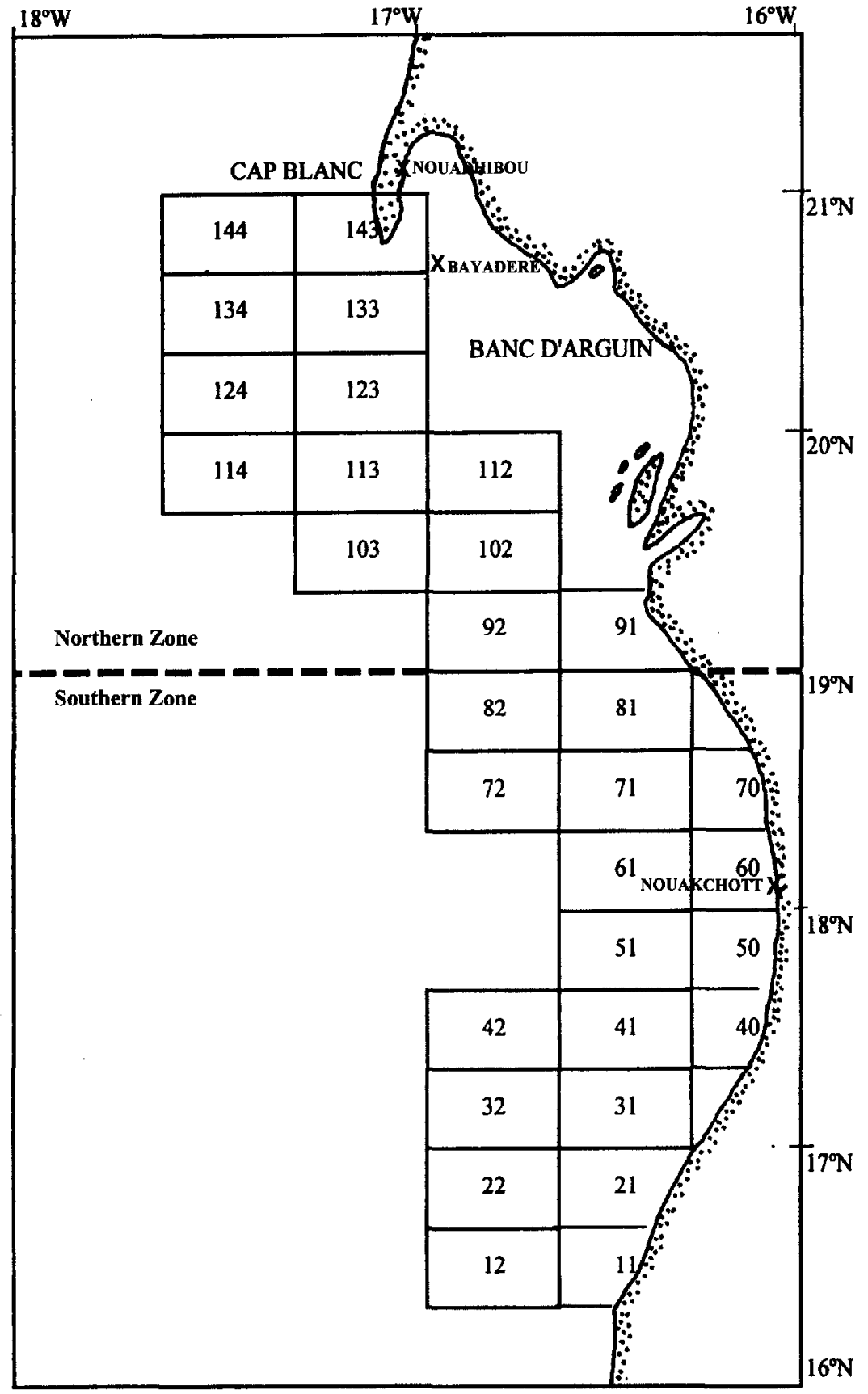


north and south of the $19^{\circ} \mathrm{N}$ latitude. This division is based on results from previous studies which indicated that these two zones appear to have distinct hydrographic characteristics [1], 29]. Likewise, the year was divided into four hydrographic seasons: a cold season (JanuaryMay), a warm season (August-October) and two transitional seasons (June-July and November-December). Bottom water temperature data from the coastal station of Bayadère $\left(20^{\circ} 40^{\prime} \mathrm{N}-17^{\circ} 04^{\prime} \mathrm{W}\right.$; [13]) are analyzed and the Coastal Upwelling Index (CUI) is estimated $[1,2,46]$ using wind data from a coastal meteorological station at Nouadhibou from 1960 to 1993 (figure 2). The CUI is expressed as the volume of water in cubic meters transported off-shore per second per $100 \mathrm{~m}$ of coastline as a result of the meridional wind stress component (Ekman transport).

Trend analysis was conducted on monthly CUI and bottom water temperature values using the Seasonal Kendall Test (SKT) for trend, a nonparametric procedure believed to be robust against outliers, collinearity and seasonality [17]. Whether the phenomena observed at local coastal stations were reflected at larger scales (the $2^{\circ} \times 2^{\circ}$ squares and larger) was investigated using the Kendall Rank correlation coefficient [6] as well as regression techniques [25].

\section{RESULTS AND DISCUSSION}

\subsection{Spatial and temporal trends of sea surface tem- perature}

Annual mean SST is about $20.2^{\circ} \mathrm{C}$ at the northern limit $\left(30^{\circ} \mathrm{N}\right.$ latitude) and $25.8^{\circ} \mathrm{C}$ at the southern limit $\left(10^{\circ} \mathrm{N}\right)$ of the study area. Between 20 and $26^{\circ} \mathrm{N}$ the average temperature is cooler and more uniform with a mean of about $19.7^{\circ} \mathrm{C}$, which reflects the persistent influence of upwelling. Mean SST is slightly warmer north of this region and significantly warmer to the south. The Mauritanian shelf, which lies between 16 and $21^{\circ} \mathrm{N}$, includes the SST transition zone between the northern and southern regions (table I, figure 3). Particular attention will be given to this region in the following sections.

The eigenvalues of the EOF analysis, performed on monthly SST deviations of the nearshore boxes (figure 1), indicate that two components account for $95 \%$ of the total variability. Subsequent components account for less than $3 \%$ each (table I). Furthermore, since the third eigenvector and subsequent components make relatively
Table I. Eigenvalues and eigenvectors of the empirical orthogonal function analysis of sea surface temperature $\left({ }^{\circ} \mathrm{C}\right)$ along the north west African coast. PRIN1. PRIN2. denote the first two orthogonal functions.

\begin{tabular}{lrrrrr}
\hline Latitude & \multicolumn{2}{c}{ EOF modes } & & \multicolumn{2}{c}{ Temperature } \\
\cline { 1 - 2 } \cline { 5 - 6 } & PRIN1 & PRIN2 & & Mean & STD \\
\hline $28-30 \mathrm{~N}$ & 0.33 & -0.05 & & 20.24 & 1.66 \\
$26-30 \mathrm{~N}$ & 0.33 & -0.06 & & 20.27 & 1.49 \\
$24-26 \mathrm{~N}$ & 0.30 & -0.23 & & 19.66 & 1.41 \\
$22-24 \mathrm{~N}$ & 0.31 & -0.32 & & 19.64 & 1.28 \\
$20-22 \mathrm{~N}$ & 0.30 & -0.43 & & 19.64 & 1.82 \\
$18-20 \mathrm{~N}$ & 0.32 & -0.18 & & 21.79 & 2.93 \\
$16-18 \mathrm{~N}$ & 0.33 & 0.01 & & 23.13 & 3.25 \\
$14-16 \mathrm{~N}$ & 0.33 & 0.23 & & 23.93 & 3.40 \\
$12-14 \mathrm{~N}$ & 0.32 & 0.43 & 24.72 & 3.25 \\
$10-12 \mathrm{~N}$ & 0.29 & 0.63 & 25.86 & 2.34 \\
\% variance & 88.50 & 6.10 & & \\
explained & & & & \\
\hline Cumulative \% & 88.50 & 94.60 & & \\
\hline
\end{tabular}

small contributions to the total SST variance, they will not be discussed further $[7,8,31,42]$.

The first component (PRIN1) reflects the seasonal signal. This first eigenvector has approximately equal loadings at all latitudes (table I, figure 4). The signal indicates in phase cooling and warming for both the northern and southern regions. The time coefficients always have positive values (i.e. maximum temperatures) in the warm water season (August-October) and negative values during the cold water season (January-May). The largest positive value appears in September, while the largest negative value occurs in March. PRIN1 accounts for $88.5 \%$ of the total variability, a percentage which indicates the dominance of the seasonal SST signal in the Atlantic. Similar studies in the Atlantic, but on larger scales, have reported values for the first eigenvector between 80 and $84 \%$ of the total variance $[32,36,42]$. A recent study of SST variability off northwest Africa using satellite imagery from a relatively shorter period (19811989) but a much larger area than we studied found that the first EOF component contained about $75 \%$ of the total SST variance [16].

Our second eigenvector (PRIN2), which contributes $6.1 \%$ of the total variance, has negative loadings at northern latitudes and positive loadings at southern latitudes. The northern and southern regions are out of phase with respect to the second component. This can be interpreted as a measure of the spatial variation of upwelling intensity. The latitudes between $18^{\circ} \mathrm{N}$ and $26^{\circ} \mathrm{N}$ have the 

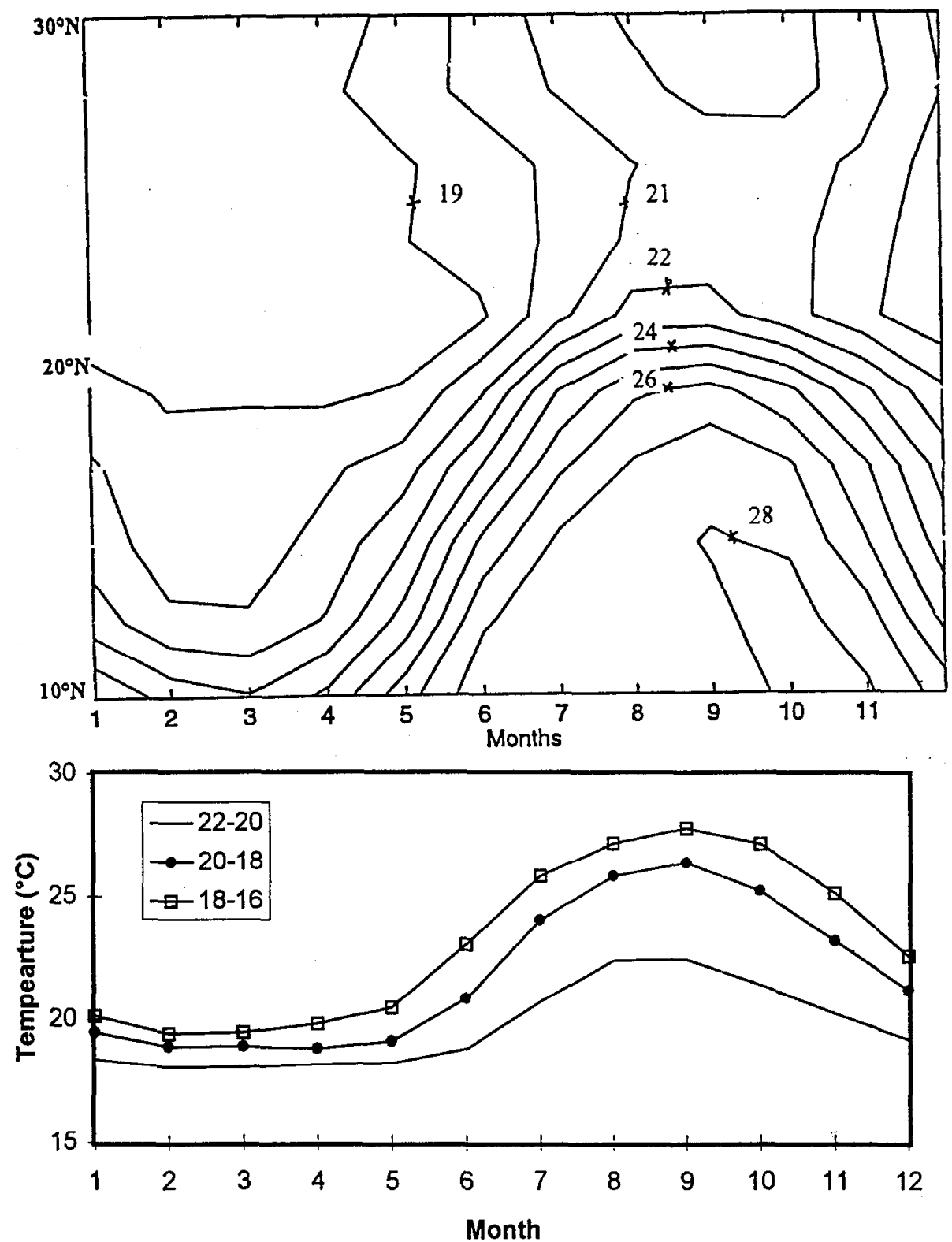

Figure 3. Contours of monthly mean sea surface temperature (top) and its evolution for selected latitudes $\left(16-22^{\circ} \mathrm{N}\right)$ along the northwest African coast (bottom).

highest negative loadings. These are known to be regions of permanent upwelling $[38,39,46]$ while north of $26^{\circ} \mathrm{N}$ and south of $18^{\circ} \mathrm{N}$ the upwelling seems to be seasonal. The temporal pattern for PRIN2 indicates a semi-annual cycle with two minima in March (cold water season) and August-September (warm water season) and two maxima in June and November-December. Plots of PRIN2 vs. PRIN1 clearly indicate the separation between the cold season (January-May) and the warm season (August-October), the latter having positive PRIN1 loadings. The transitions between these two water seasons tend to have positive PRIN2 loadings. In their study, Hernandez-Guerra and Nykjaer [16] also point out the "out of phase behavior" between northern and southern regions alluded to earlier. Direct comparison of the time series of projection coefficients found in the two studies 

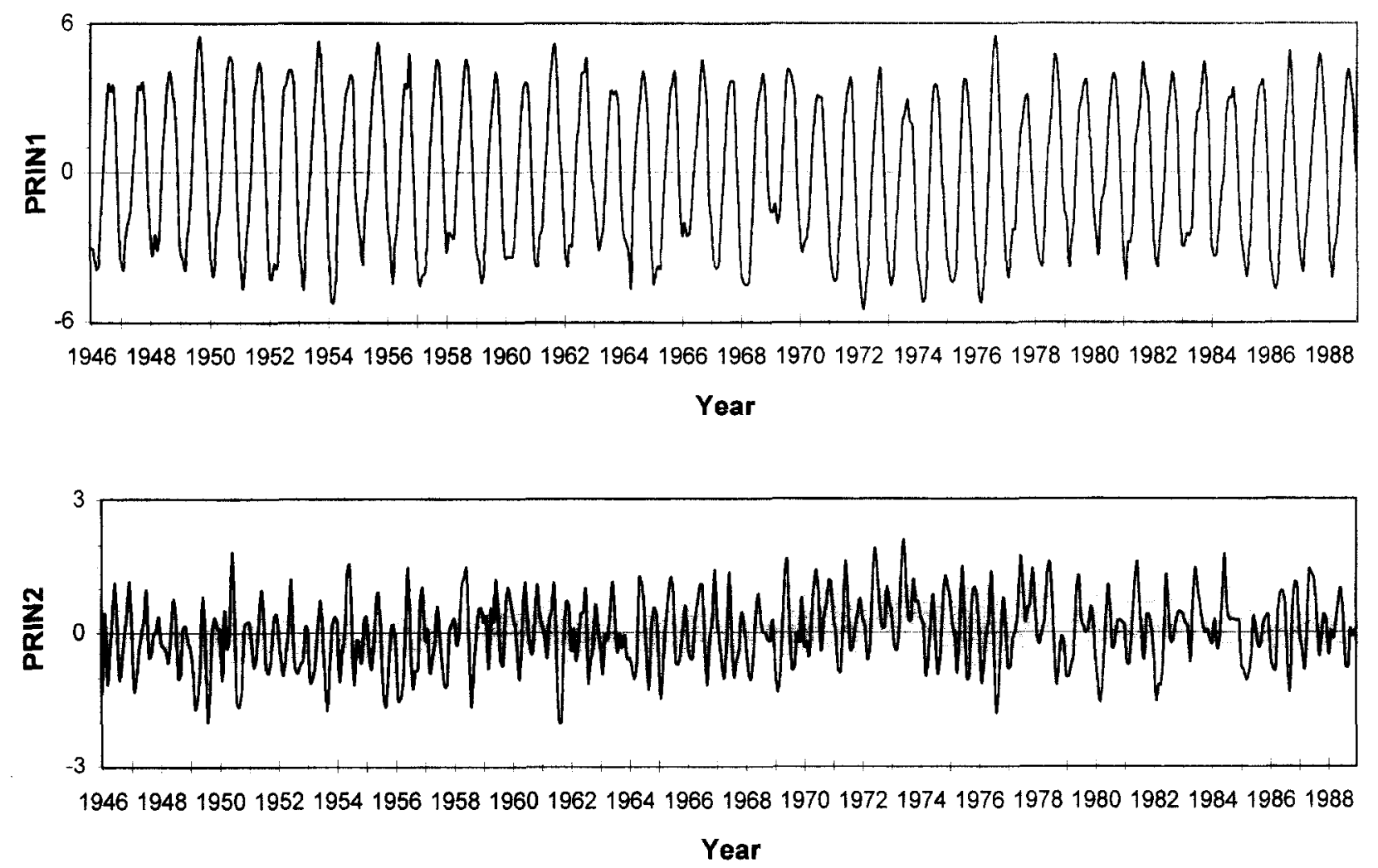

Figure 4. Plots of time coefficients for the first two orthogonal functions (i.e. PRIN1 and PRIN2) for sea surface temperature along the northwest African coast $\left(10-30^{\circ} \mathrm{N}\right)$.

is difficult though because of significant differences in study scales - ours is limited in space and extensive in time, while theirs is the opposite.

Time series plots of PRIN2 indicate an increase in the amplitude of the separation between regions of permanent upwelling and regions of seasonal upwelling (slope of regression: $0.01{ }^{\circ} \mathrm{C} \mathrm{yr}^{-1}, \mathrm{P}<0.001$; figure 5). A closer look reveals a long-term cooling trend for the regions between 20 and $26^{\circ} \mathrm{N}$ over the study period. The reverse is observed for the southern regions, where considerahle heating occurred. What then is happening in the transitional waters between these two regions? This question was addressed by plotting SST anomalies. The SST anomaly was computed as heing equal to the mean monthly SST in a given year minus the long-term average. Interestingly, when plotting SST anomalies for the warmest months (August-October) at the above latitudes, a downward (cooling) trend can be easily identified (slope of regression: $-0.026^{\circ} \mathrm{C} / \mathrm{yr}^{-1}, \mathrm{P}<0.001$; figure 6), while south of $14^{\circ} \mathrm{N}$ and north of $22^{\circ} \mathrm{N}$ no such trend is observed. It is hypothesized that a shift in the time and/or strength of upwelling is occurring. This may be seen by correlating the second principal component, which was interpreted as being a measure of the strength of the spatial (latitudinal) separation of northern and southern regions, with upwelling intensity. The correlation is strongest during the warm water season (August-September; Kendall Tau $=-0.73, P=0.0001$ ). Also, the correlation was significantly higher between PRIN2 coefficients and upwelling during the transitional warmto-cold-water season (November-December; Kendall Tau $=-0.43$ ). This might be a reflection of an earlier-thanusual invasion of the shelf by southward-flowing cold water masses from the Sahara Current, i.e. around November-December, warm waters are pushed quickly off the shelf earlier than in the beginning of the study's time series.

Complex EOF analyses performed on wind vectors from the same nearshore Marsden squares as the SST data, after removal of the means revealed that the first principal component accounted for $57 \%$ of the total variance, while the second EOF mode contributed about $27 \%$. The first EOF represents a pattern which is strongest in the south and rotates approximately $145^{\circ} \mathrm{clockwise}$ from north to south, 


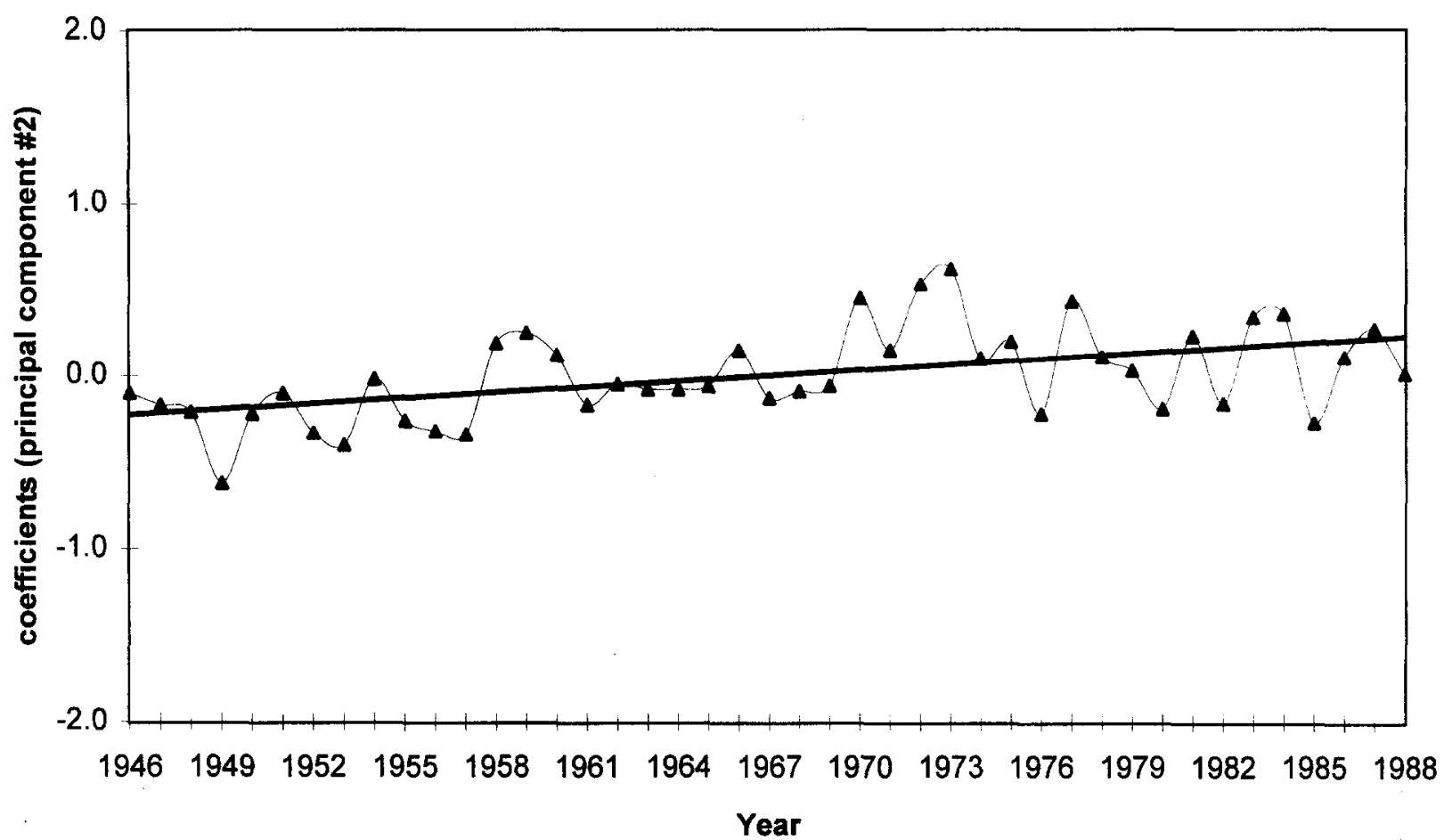

Figure 5. Plot showing linear trend (thick line) for annual means of the second principal component time coefficients for sea surface temperature along the northwest African coast, $10-30^{\circ} \mathrm{N}$ (slope $=0.01^{\circ} \mathrm{C} \mathrm{yr}^{-1}$ ).

suggesting a convergence near the middle of the pattern. The second EOF pattern rotates approximately $45^{\circ}$ counterclockwise from north to south. It weakens initially moving from north to south and then strengthens slightly in the southernmost boxes. The time variability of the first EOF is primarily seasonal in nature. This signal is best resolved for the north-south component in the five northern latitude boxes and for the east-west component in the five southern latitude boxes. The other component, while still containing a dominant annual signal, is more variable in nature. The time variability of the second EOF is also dominated by a seasonal variability, but significant energy is found at a half-year period. The annual variability is, again, best resolved in the north-south winds in the northernmost squares and the east-west winds in the southern squares. The latter contribute strong pulses towards the east. We have been unable to uniquely associate the dominant wind EOFs with those of the SST. In fact, the first SST EOF has correlation coefficients of 0.32 and 0.38 with the first and second wind EOFs, respectively. The second SST EOF has a correlation coefficient of 0.20 with the second wind EOF, presumably because of the presence of a strong semi-annual signal in each projection coefficient time series. A closer look in time and space reveals a significantly high correlation between the meridional wind contribution from the first EOF and SST contributions from each EOF in each latitude box (table II). For instance, between June and December, it appears that the meridional wind from the first EOF correlates well with SST contributions from each of the first and second SST EOF modes. These correlations generally indicate the out-of-phase relationship between northern and southern zones. The northernmost regions are negatively correlated with the first EOF and positively correlated with the second EOF. The reverse is observed for the southernmost boxes (table II).

\subsection{The Mauritanian shelf as a transitional region}

We now consider smaller scales $\left(20^{\prime} \times 20^{\prime}\right)$ of the Mauritanian Economic Exclusive Zone (EEZ: figure 2). Over the Mauritanian shelf, average monthly SST exhibits a strong seasonal pattern in both the northern and southern zones, separated by the $19^{\circ} \mathrm{N}$ latitude (figure 7, table III). From January to May cold waters are observed over the whole continental shelf. Later in the year, SST increases to a maximum around August-September (warm season) and then drops quickly toward the end of the year. On 


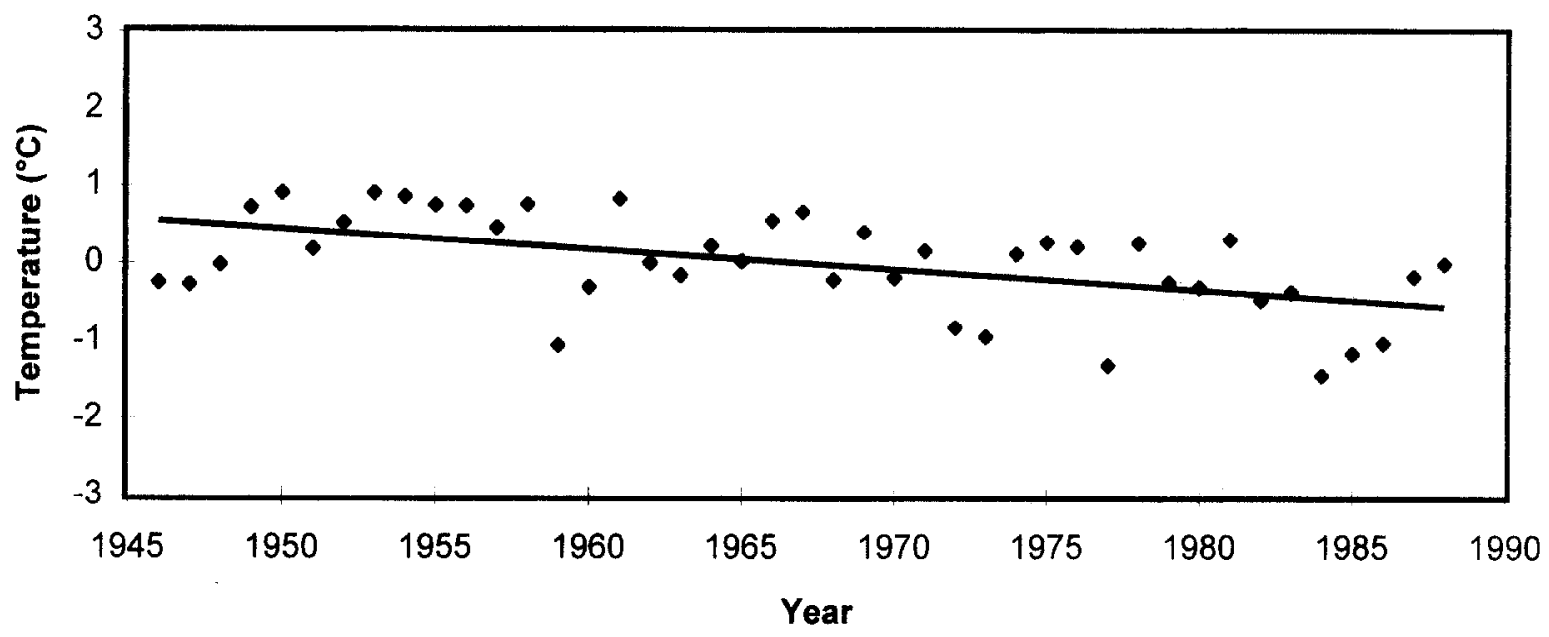

Figure 6. Plot of annual means of sea surface temperature anomalies $\left({ }^{\circ} \mathrm{C}\right)$ showing a linear cooling trend during the warm water season (August-October) for a selected $2^{\circ} \times 2^{\circ}$ square $\left(16-18^{\circ} \mathrm{N}\right.$ ) along the northwest African coast (slope $=-0.026^{\circ} \mathrm{C} \mathrm{yr}^{-1}$ ).

Table II. Correlation matrix for the contribution from the meridional wind of the first EOF wind mode and the first two modes of sea surface temperature (Mode1 and Mode2) by hydrographic season along the northwest African coast.

\begin{tabular}{|c|c|c|c|c|c|c|c|c|}
\hline \multicolumn{9}{|c|}{ First EOF MODE } \\
\hline & \multicolumn{2}{|c|}{ January-May } & \multicolumn{2}{|c|}{ June-July } & \multicolumn{2}{|c|}{ August-October } & \multicolumn{2}{|c|}{ November-December } \\
\hline & Mode1 & Mode2 & Mode1 & Mode2 & Mode1 & Mode2 & Mode1 & Mode2 \\
\hline \multicolumn{9}{|l|}{ Latitude } \\
\hline $28-30 \mathrm{~N}$ & - & 0.35 & -0.30 & 0.37 & -0.43 & - & - & 0.38 \\
\hline $26-30 \mathrm{~N}$ & - & 0.35 & -0.35 & 0.41 & -0.44 & - & - & 0.39 \\
\hline $24-26 \mathrm{~N}$ & - & 0.35 & -0.25 & 0.33 & -0.41 & - & - & 0.37 \\
\hline $22-24 N$ & - & 0.35 & -0.19 & 0.27 & -0.39 & - & 0.24 & 0.35 \\
\hline $20-22 \mathrm{~N}$ & - & 0.31 & - & - & -0.30 & -- & 0.37 & 0.26 \\
\hline $18-20 \mathrm{~N}$ & 0.28 & - & 0.46 & -0.44 & - & -0.38 & 0.43 & - \\
\hline $16-18 \mathrm{~N}$ & 0.21 & -0.20 & 0.47 & -0.48 & 0.27 & -0.44 & 0.31 & -0.23 \\
\hline $14-16 \mathrm{~N}$ & - & -0.27 & 0.45 & -0.48 & 0.36 & -0.41 & - & -0.30 \\
\hline $12-14 \mathrm{~N}$ & - & -0.30 & 0.44 & -0.47 & 0.40 & -0.37 & - & -0.33 \\
\hline $10-12 \mathrm{~N}$ & - & -0.31 & 0.44 & -0.47 & 0.41 & -0.35 & - & -0.34 \\
\hline
\end{tabular}

- , denotes that the correlation is not statistically significant at $\alpha=0.05$.

average, the northern zone has much colder SST than the south (figure 7). The seasonal warming-cooling cycle and north-south (meridional) gradient are consistent with the physical processes active in the area (figure 3). At the beginning of the year, upwelling is very intense and the southward-flowing, cold Sahara Current invades the shelf. This period is generally characterized by relatively weak SST variability $[12,21]$. Average SST is $18.4^{\circ} \mathrm{C}$ for the whole shelf (standard deviation $\pm 0.97{ }^{\circ} \mathrm{C}$; table III). Beginning in June, SST rises due to increased solar radiation and a change in the upwelling intensity, especially in the southern part of the EEZ where the strongest thermal gradients are observed [11, 21, 22, 29]. During the warm season (August-October), the trade winds favorable to the development of upwelling weaken, and the inner and outer shelves are occupied by a warm, northward-flowing current, the Mauritania Current. Average SST is $24.6^{\circ} \mathrm{C}$ for the whole shelf (standard deviation $\pm 2.59^{\circ} \mathrm{C}$, table III). From November to December, there is a cooling of shelf SST and a rather quick return to the initial conditions, where isotherms are distributed parallel to the isobaths [12]. Comparison of figures 3 and 7 indicates a strong visual correlation. Clearly, the finescale, inner-shelf thermal patterns vary in phase with the 


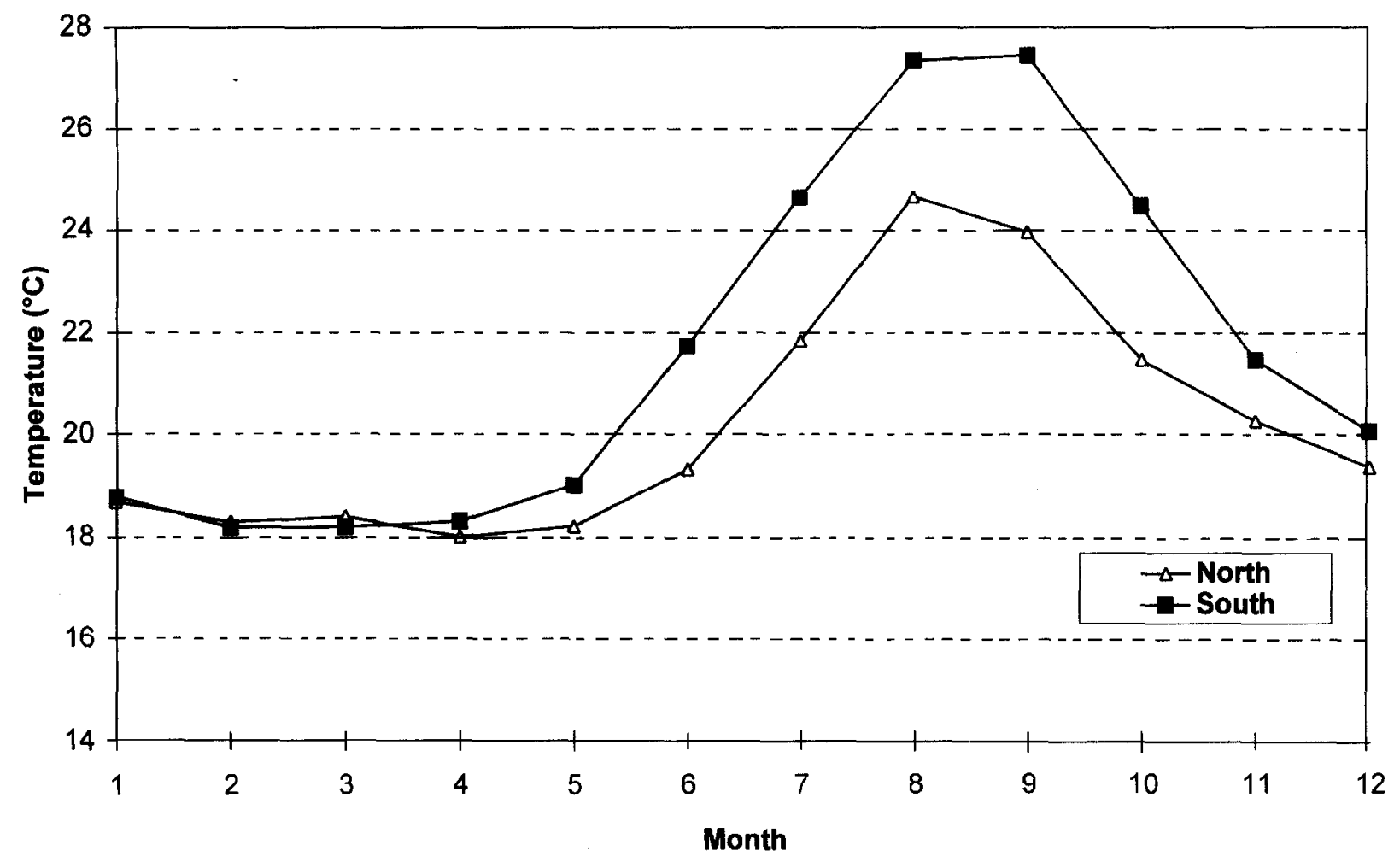

Figure 7. Long-term average monthly sea surface temperature $\left({ }^{\circ} \mathrm{C}\right)$ for the northern and southern zones of the Mauritanian shelf.

Table III. Mean sea surface temperaturses $\left({ }^{\circ} \mathrm{C}\right.$ ) and their standard deviations (std) for the Mauritanian shelf during the different hydrographic seasons.

\begin{tabular}{lcccccc}
\hline Season & Southern zone & std & Northern zone & std & Whole shelf & std \\
\hline Cold (January-May) & 18.52 & 0.95 & 18.21 & 0.97 & 18.43 & 0.97 \\
Cold-warm (June-July) & 21.45 & 1.99 & 20.31 & 1.80 & 21.01 & 1.99 \\
Warm (August-Oct.) & 25.60 & 2.57 & 23.30 & 1.68 & 24.58 & 2.59 \\
Warm-cold (Nov.-Dec.) & 20.71 & 1.61 & 20.05 & 1.00 & 20.49 & 1.46 \\
\hline
\end{tabular}

larger scale characteristics of the outer shelf and slope. Therefore, the Mauritanian shelf plays the role of transition zone between the northern zone of permanent upwelling and the southern zone of seasonal upwelling in the northwest African region. This zone may serve as a sensitive indicator of climatic changes in the region.

\subsection{Link to coastal stations}

The CUI can provide some insights into onshore and offshore Ekman transport variability $[14,37]$. The CUI computed at coastal stations is derived from and reflects the regional wind patterns. In the northern part of the Mauritanian shelf the mean wind stress has a steady component from the north favorable for the development of yearround coastal upwelling, with maximum intensity from
March to July (figure 8). Bottom water temperatures at the Bayadère coastal station during the cold water season (1963-1988) show modest similarities with the upwelling intensity (1960-1993). Bottom water temperatures are colder at times of high CUI values and warmer at times of lower CUI values (figure 9). In the southern part, CUI is much lower than in the north because of a reduction in wind speed and increased directional variability $[28,30]$.

Analysis of yearly CUI anomalies in Nouadhibou (19601988) revealed a succession of years with high upwelling intensity followed by years of low intensity. The period of the cycle was approximately ten years; the mid-1960s, 1970s and 1980s showed high CUI values (figure 10). Examining SST long term variability over the Mauritanian shelf, it appears that the study area went through 


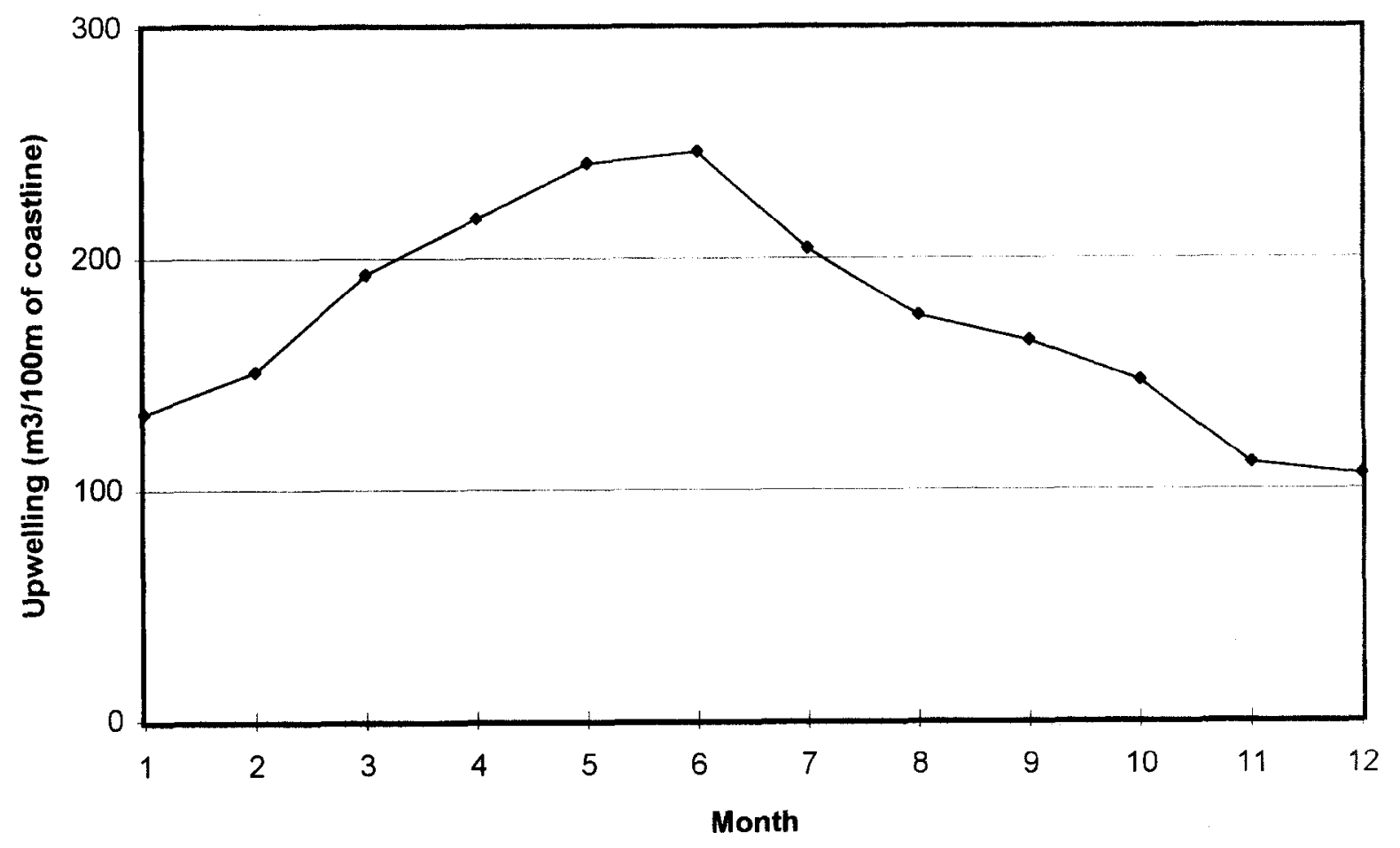

Figure 8. Temporal evolution of monthly mean upwelling intensity $\left(\mathrm{m}^{3} / \mathrm{s}\right.$ per $100 \mathrm{~m}$ of coastline) off Mauritania estimated from the Nouadhibou coastal station data (1960-1993)

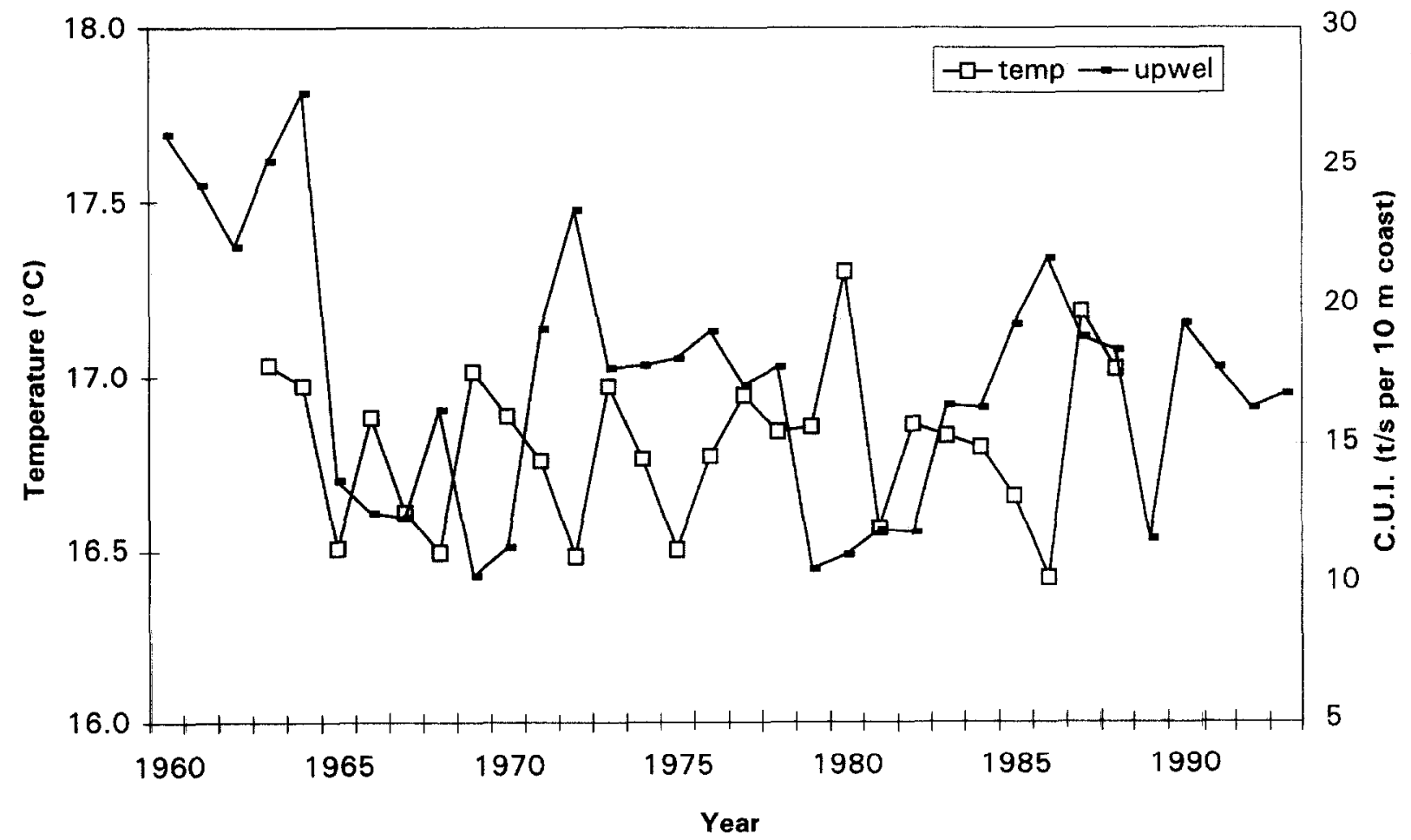

Figure 9. Yearly average bottom water temperature at Bayadère (1963-1988) and Coastal Upwelling Index at Nouadhibou (1960-1993) during the cold water season, January-May (correlation coefficient $=0.3$ ). 


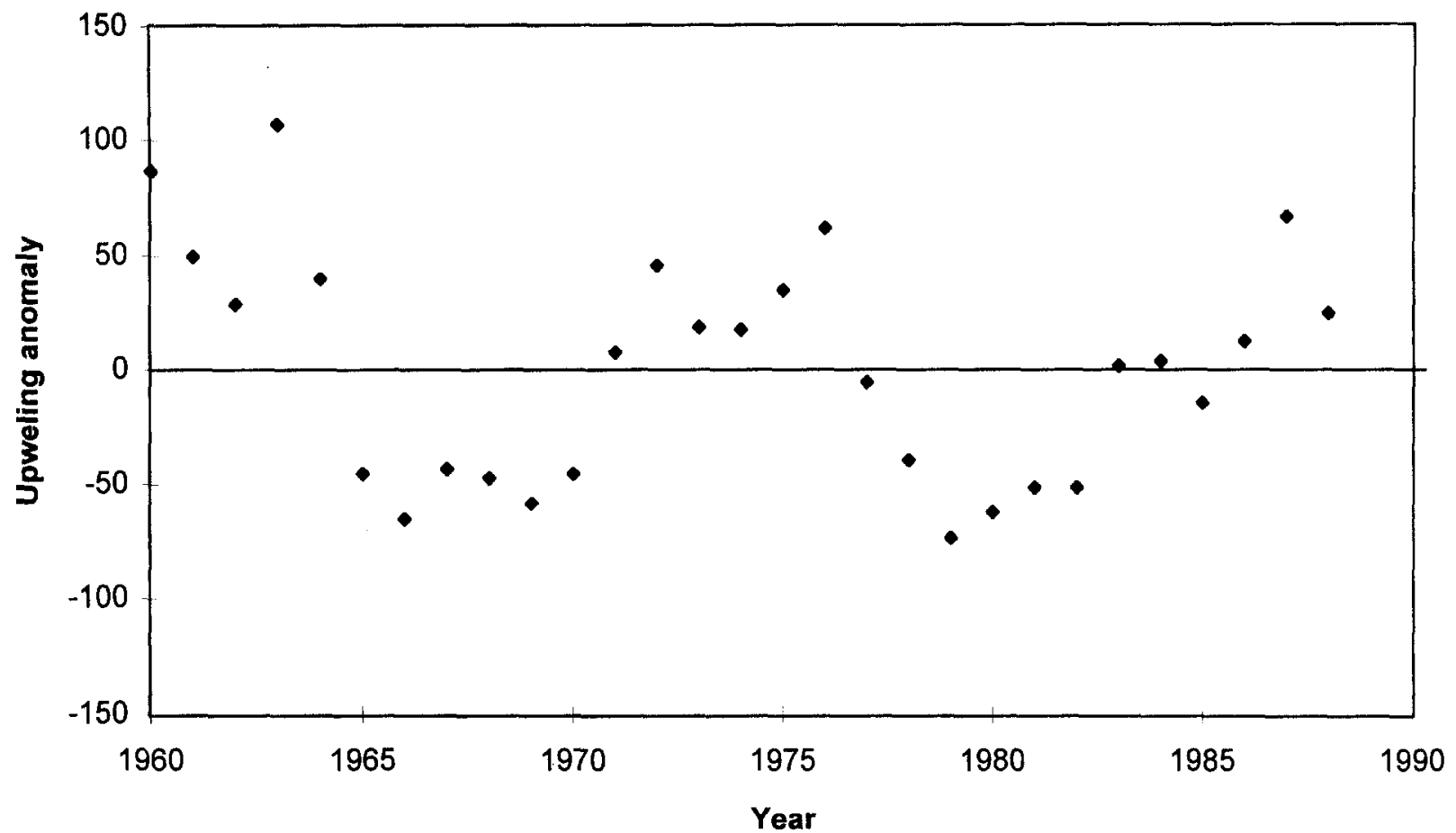

Figure 10. Plot of upwelling anomalies (yearly value minus long-term average value) for Coastal Upwelling Index calculated during the warm water season (August-October) at the Nouadhibou coastal station (1960-1988).

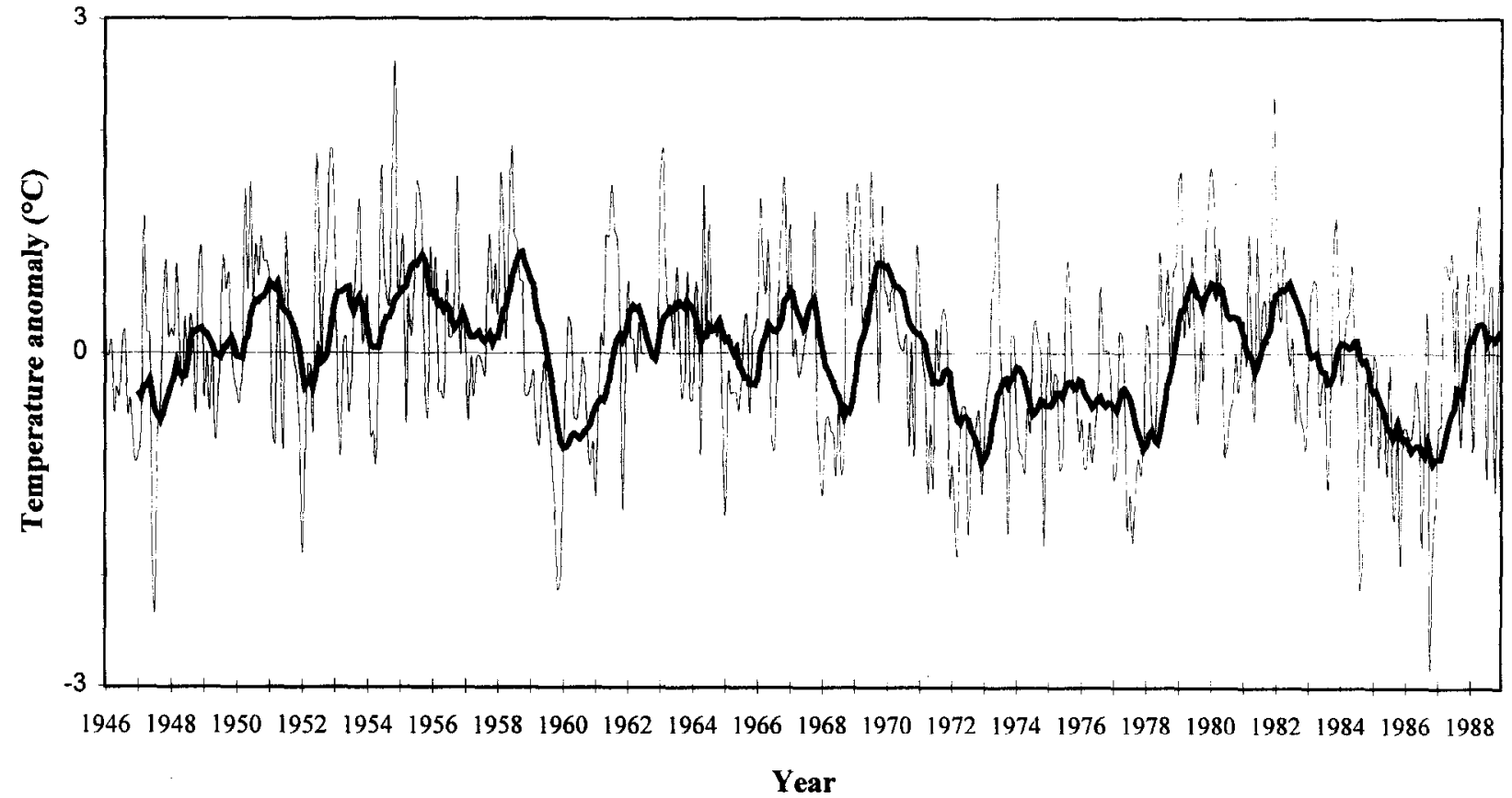

Figure 11. Plot of monthly sea surface temperature anomalies $\left({ }^{\circ} \mathrm{C}\right)$ at latitudes of $16-18^{\circ} \mathrm{N}$ on the northwest African coast from 1946 to 1988 . Also shown is the 13 period moving average (thick line). 
successive cooling and warming events (figure $/ I$ ) in agreement with the upwelling index values reported above for the same time period. In general, it can be seen that the middle years of some decades (e.g. 1972- 1978; 1984-1988) show relatively negative anomalies (cooling) in the Mauritanian EEZ (figure 11). This cooling period was then followed by a warming trend (19891993, [29]). These cooling and warming patterns may be part of a long-term process affecting the northwest African coast and are the topic of on-going research.

There appears to be a strong agreement between SST on the continental shelf $\left(18-20^{\circ} \mathrm{N}\right)$ and CUI computed at the Nouadhibou coastal station during the cold water sea son (January-May, figure 12). Regression analysis indicates the expected negative association between SST and CUI computed at the Nouadhibou station $(\mathrm{P}<0.0001)$. This coastal station, therefore, provides an adequate indicator of thermal oceanographic processes in the Mauritanian shelf waters, both surface and bottom temperatures. In fact, the coastal station data are an indication of the larger-scale wind field. Regression analysis showed that the coastal meridional wind component at Nouadhibou is about 0.8 of the same offshore wind component in the $22-24^{\circ} \mathrm{N}$ latitude box (correlation coefficient $=0.5$ ).
In an efforl to determine the spatial scale associated with the observed temporal variability, we correlated our local time series with a large number of extensive acednographic patterns used in climate studies (table $I V$ ). When examining this correlation matrix, atmospheric pressure and temperatures correlate well with large-scale parameters such as wind and temperature. The results, again, exhibit the out-of-phase behavior between the zones north and south of the Mauritanian shelf. For instance, an increase in the difference between minimum and maximum air temperature at Nouadhibou is associated with low and high values of the southward wind component in the northern and southern regions, respectively. The extent to which this mercly reflects a seasonal pattern in each parameter time series or a more important indication of teleconnections is not presently known, but the possibility of using coastal measurements in this transition region as an indicator of larger-scale variations is tantalizing.

The representativeness of coastal stations for larger-scale variability is further supported when investigating associ ations between CUI and such global climatic indices as the East Atlantic Pattern (EA). The EA and the East Atlantic Jet (EA-jet) are two of the three most prominent

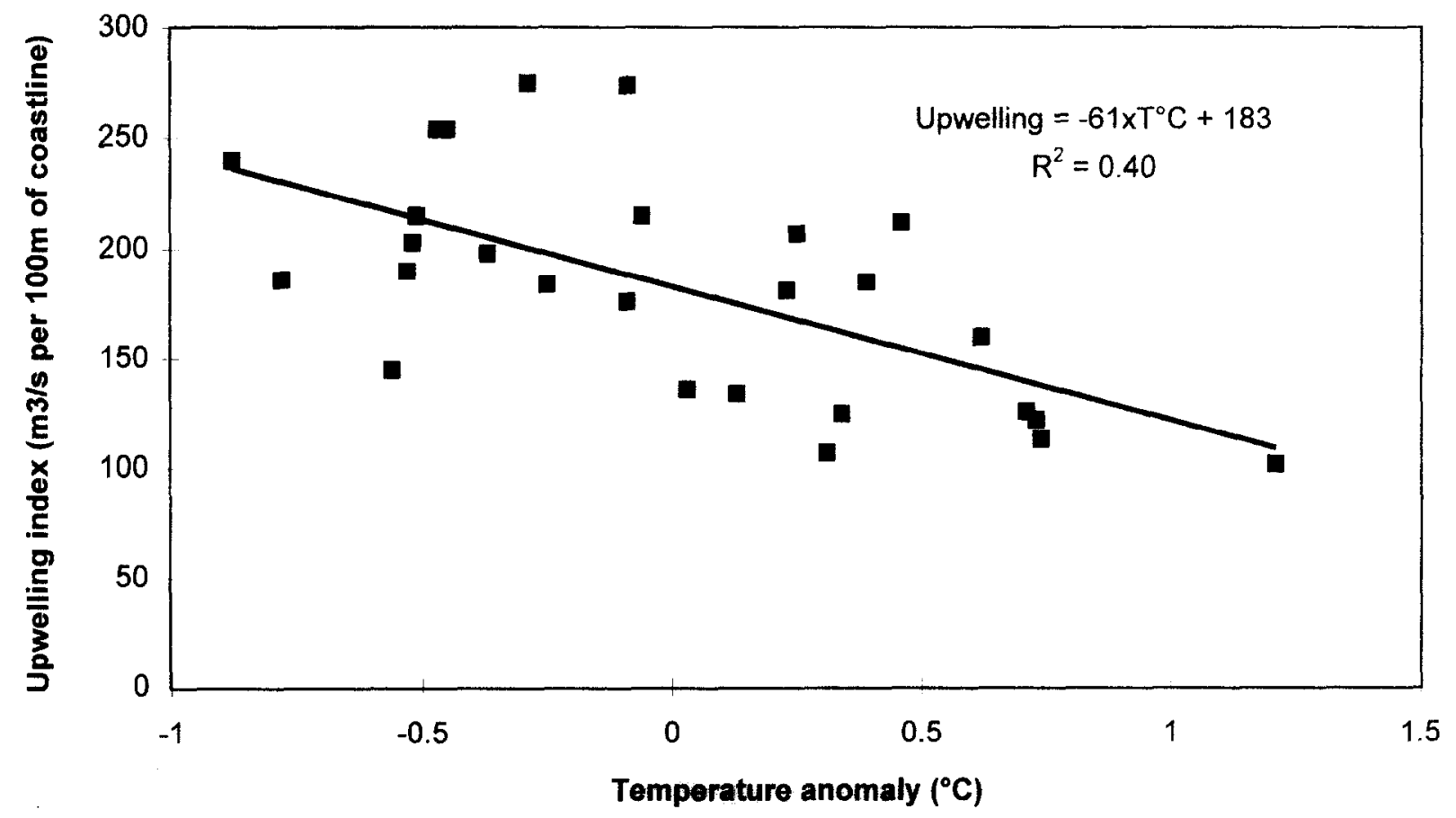

Figure 12. Temporal plot of sea surface temperature anomaly at selected latitudes $\left(18-20^{\circ} \mathrm{N}\right)$ of the Mauritanian shelf and Coastal Upwelling Index at Nouadhivou station during the cold water season, January-May (1960-1988). 
Table IV. Correlation matrix between hydrological and meteorological parameters at the coastal station of Nouadhibou and the wind meridional component along the northwest African coast.

\begin{tabular}{lcccc}
\hline \multicolumn{5}{c}{ Coastal station indices } \\
\hline Latitude & Vy & Min-Max & Pressure & Temp. \\
\hline $28-30 \mathrm{~N}$ & 0.40 & 0.37 & 0.51 & -0.39 \\
$26-30 \mathrm{~N}$ & 0.40 & 0.33 & 0.53 & -0.45 \\
$24-26 \mathrm{~N}$ & 0.39 & 0.27 & 0.48 & -0.38 \\
$22-24 \mathrm{~N}$ & 0.50 & 0.14 & 0.48 & -0.34 \\
$20-22 \mathrm{~N}$ & 0.57 & - & 0.37 & -0.16 \\
$18-20 \mathrm{~N}$ & 0.45 & -0.20 & - & 0.19 \\
$16-18 \mathrm{~N}$ & - & -0.42 & -0.45 & 0.71 \\
$14-16 \mathrm{~N}$ & - & -0.39 & -0.67 & 0.82 \\
$12-14 \mathrm{~N}$ & -0.14 & -0.37 & -0.71 & 0.85 \\
$10-12 \mathrm{~N}$ & -0.16 & -0.40 & -0.72 & 0.87 \\
\hline
\end{tabular}

- , denote the correlation is not statistically significant at $\alpha=0.05$.

$\mathrm{Vy}$ : meridional wind component $\left(\mathrm{m} \mathrm{s}^{-1}\right)$ at Nouadhibou

Min-Max: difference between min and max air temperature $\left({ }^{\circ} \mathrm{C}\right)$ at Nouadhibou

Pressure: atmospheric pressure (mbar) at Nouadhibou

Temp: bottom temperature $\left({ }^{\circ} \mathrm{C}\right)$ at Bayadère

Table V. Correlation matrix for Kendall Tau correlation coefficient between coastal indices in Mauritania and various scale and global climatic indices.

\begin{tabular}{lrrrr}
\hline & EA & EA-JET & SATL & TROP \\
\hline Temp. & -0.54 & 0.39 & -0.70 & -0.45 \\
NDB_Pressure & 0.53 & -0.53 & 0.41 & 0.22 \\
NDB_MinMax & 0.48 & -0.39 & 0.36 & 0.24 \\
CUI & -0.18 & 0.33 & 0.43 & 0.34 \\
Vy & 0.23 & -0.37 & -0.38 & -0.32 \\
\hline
\end{tabular}

Temp: bottom temperature $\left({ }^{\circ} \mathrm{C}\right)$ at Bayadère

NDB_Pressure: atmospheric pressure (mbar) at Nouadhibou

NDB_MinMax: difference between $\min$ and $\max$ air temperature $\left({ }^{\circ} \mathrm{C}\right)$ at Nouadhibou

CUI: coastal upwelling index $\left(\mathrm{m}^{3} / \mathrm{s}\right.$ per $100 \mathrm{~m}$ coastline $)$ at Nouadhibou

Vy: meridional wind component $\left(\mathrm{m} \mathrm{s}^{-1}\right)$ at Noudhibou

EA: East Atlantic pattern*

EA-JET: East Atlantic Jet*

SATL: South Atlantic SST $(0-20 \mathrm{~S}, 30 \mathrm{~W}-10 \mathrm{E}) *$

TROP: Tropical zone SST $(10 \mathrm{~S}-10 \mathrm{~N}, 0-360)^{*}$

* Data source: NOAA

modes of low-frequency variability over the North Atlantic [3, 43]. Both EA and EA-jet consist of a north-south dipole of pressure anomaly centers which span the North Atlantic. The former appears in all months except MayAugust while the latter appears mainly between April and August. There is negative correlation between CUI and EA (Kendall Tau $=-0.54$ ) and positive correlation between CUI and EA-jet (Kendall Tau $=0.39$, table V).
Moreover, the correlation is much stronger for the warm water season where the correlation coefficients reach values of -0.6 and 0.6 for the EA and EA-jet in SeptemberOctober and August, respectively. These results arc consistent with those from a previous study that found strong correlations between ship-recorded pressures and scalevel coastal stations along the tropical Atlantic coast of Africa [4]. Interestingly enough, CUI and temperature data at the Nouadhibou station seem to correlate best with temperatures from the South Atlantic $\left(0-20^{\circ} \mathrm{S}, 30^{\circ} \mathrm{W}-\right.$ $\left.10^{\circ} \mathrm{E}\right)$ and the Tropics $\left(10^{\circ} \mathrm{S}-10^{\circ} \mathrm{N} ; 0-360^{\circ}\right)$; the Kendall correlation coefficient values are 0.70 and 0.45 , respectively (table $V$ ). The most important point, though, is that time series from a single coastal station are strongly correlated with the variations of larger-scale oceanic patterns and may serve as a surrogate for these patterns.

\section{CONCLUSION}

Investigations of the timing and structure of SST reveal the seasonal variability of complex spatial patterns along the northwest African coast. Of interest are the differences between northern regions with permanent upwelling and southern regions where the upwelling is seasonal. Likewise, it seems likely that shifts in the extent and timing of upwelling are taking place, partly because of changes in wind direction and intensity. The Mauritanian shelf, a region of confluence between colder waters in the north and warmer waters in the south as well as upwelling waters, seems to play an important role as a transition between temperate and tropical regimes. Moreover, the likely strong relationship between SST, over parts of the shelf, and CUI computed at a coastal station may be an indication that coastal stations can give an nsadequate representation of the oceanographic processes at larger scales. The processes involved, however, warrant further investigation.

\section{Acknowledgment}

The first author would like to thank Dr. Inoue Masamichi for providing the SST COADS data set and for invaluable discussions. We also would like to thank the two anonymous reviewers whose helpful comments and suggestions led to an improved version of the manuscript. 
[1] Bakun A., Daily and weekly upwelling indices, west coast of North America, 1967-73, NOAA Tech. Rep. NMFS SSRF. $671(1975) 103 \mathrm{p}$.

[2] Bakun A.. Mclain D.R., Mayo F.V., The mean annual cycle of coastal upwelling off western North America as observed from surface measurements, U.S. Fish. Bull. 72 (3) (1976) 843-844.

[3] Barnston A.G., Livezey R.E., Classification, seasonality and persitence of low-frequency atmospheric circulation patterns. Mon. Wea. Rev. 115 (1987) 1083-1126.

[4] Bigg G.R., Comparison of coastal wind and pressure trend over the tropical Atlantic, 1946-1987, Intern. J. Climatology 13 (1993) 13,000-13, 011.

[5] Boje R., Tomczak M., Ecosystem analysis and the the definition of boundaries in upwelling regions, in: Upwelling ecosystems. Boje R., Tomczack M. (Eds.), Springer-Verlag. New York, 1978, 3-11.

[6] Conover W.J., Practical nonparametric statistics. Wiley, New York, 1980, 493 p.

[7] Craddock J.M., A meteorological application of principa component analysis, The Statistician, 15 (2) (1965) 143-156.

[8] Craddock J.M., Problems and prospects for eigenvector analysis in meteorology, The Statistician, 22 (1973) 133-145.

[9] Cuq F., Remote sensing of sea surface and coastal features in the area of the golfe d'Arguin, Mauritania, in: Ecological studies in the coastal waters of Mauritania, Wolff W.J.J., van der Land P.H., Nienhuis and P.A.W.J. de Wilde (Eds.), Hydrobiologia 258 (1993) 33-40.

[10] Cury P., Roy C. (Eds.) Pêcheries Ouest Africaines, Variabilité, Instabilité et Changement, ORSTOM/ISPM/CNROP/CRODT/ CROA/FRUB. ORSTOM, Edit., 1991, 525 p.

[11] Dubrovin B., Mahfoudh M., Ould Dedah S., La ZEE mauritanienne et son environnement géographique, géomorphologique et hydroclimatique, in: L'environnement, les ressources et les pêcheries de la ZEE mauritanienne, Chavance P., Girardin M. (Eds.) Bull. Centr. Nat. Rech. Oceanogr. Pêches, Nouadhibou, 23 (1991) 6-27.

[12] Dubrovin B., Ould Dedah S., Atlas Hydrologique de la Baie du Lévrier, Mauritanie, Bull. Centre Nat. Rech. Oceanogr. Pêches, Nouadhibou, 25 (1991) 46 p.

[13] Dubrovin B., Ould Dedah S., Optimisation des prélèvements de la température de l'eau au niveau de deux stations cotières: Bayadère and Gazelle (Mauritanie), Bull. Centre Nat. Rech. Oceanogr. Pêches, Nouadhibou, 21 (1990) 38-49.

[14] Ekman V.W., On the influence of the earth's rotations on ocean-currents, Arkiv för matematik, astronomi, och fysik, 2 (1905) $1-53$.

[15] Hempel G. (Ed.) The Canary current, studies of an upwelling system, Rapp. P.-v. Réun. Cons. Int. Explor. Mer, 180 (1982) $455 \mathrm{p}$.
[16] Hernandez-Guerra A.. Nykjær L., Sea surface temperature variability off north-west Africa: 1981-1989, Int. J. Rem. Sens. 12 (1997) 2539-2558.

[17] Hirsh R.M., Slack J.R., Smith R.A., Techniques of trend analysis for monthly water quality data, Water Resources Res. 18 (I) (1982) 107-121.

[18] Johnson R.A., Wichern D.W., Applicd multivariate statistical analysis (3rd ed.), Prentice-Hall, Inc., New Jersey, 1992. $642 \mathrm{p}$.

[19] Kundu P.K.. Allen J.S., Some three-dimensional characteristics of low-frequency current fluctuations near the Oregon coast, J. Phys. Oceanogr. 6 (1976) 181-199

[20] Letaconnoux R., Went A.E.J. (Eds.) Symposium sur les ressources vivantes du plateau continental atlantique Africain du Détroit de Gibraltar au Cap Vert, Rapp. P.-v. Réun. Cons. int. Explor. Mer, 159 (1970) 289 p.

[21] Loktionov Y., Contribution à l'analyse d'intensité de l'upwelling près du Cap Blanc (Mauritanie) à partir des températures de l'eau à la station "standard" Bayadère, Bull. Centre Nat. Rech. Oceanogr. et Pêches, Nouadhibou, 18 (1989) 1-9.

[22] Loktionov Y., Mahfoudh M., Analyse des variations de la température de l'eau de surface le long des côtes mauritaniennes, in: Josse E. (Ed.), Les ressources halieutiques de la ZEE mauritanienne, description, évaluation et aménagement, Rapport du $2^{2}$ Groupe de travail CNROP/FAO/ORSTOM, Nouadhibou, Mauritanie, 1988, FAO, COPACE/PACE séries, 89/48 (1989) $237 \mathrm{p}$.

[23] Longhurst A.R., Analysis of marine ecosystems, Academic Press, London, 1981, $741 \mathrm{p}$.

[24] Mittelstaedt E., The ocean boundary along the northwest African coast, Circulation and Oceanographic properties at the sea surface, Prog. Oceanogr. 26 ( 1991 ) 307-355.

[25] Myers R.H., Classical and modern regression with applications, Duxbury Press, Boston, 1986, 459 p.

[26] Neshyba S.J., Mooers Ch. N.K., Smith R.L., Barber R.T. (Eds.) Poleward flows along eastern ocean boundaries, Coast. Est. Studies, 34 (1989) 374 p.

[27] Nykxjer L... Van Camp L., Seasonal and interannual variability of coastal upwelling along northwest Africa and Portugal from 1981 to 1991. J. Geophys. Res. 99 (C7) (1994) 14197-14207.

[28] Ould Dedah S., Shaw R.F., Wiseman W. Jr., On wind flow pat terns and upwelling in Mauritania. CNROP-INOC Workshop on Water Mass Circulation, Pollution and their Impact on the Living Resources of the Centre-East Atlantic Region, Nouadhibou, 20-2.3 July, 1996, 1-15.

[29] Ould Dedah S., Modelling a Multispecies Schooling Fishery in an Upwelling Environment, Mauritania, West Africa, Ph.D Disssertation, Louisiana State University, Baton Rouge. Louisiana, USA (1995) $178 \mathrm{p}$.

[30] Ould Dedah S., Wind, surface water temperature, surface salinity and pollution in the area of the Banc d'Arguin Mauritania, 
in: Wolff W.J.J., van der Land P.H., Nienhuis, de Wilde P.A.W.J. (Eds.), Ecological studies in the coastal waters of Mauritania, Hydrobiologia, 258 (1993) 9-20.

[31] Overland J.E., Preisendorfer R.W., A significance test for principal components applied to a cyclone climatology, Mon. Wea. Rev. 110 (1) (1982) 1-4.

[32] Picaut J., Major dynamics affecting the eastern tropical Atlantic and Pacific Oceans, CalCOFI Rep., 26 (1985) 41-50.

[33] Preisendorfer R.W., Mobley C.D., Principal component analysis in meteorology and oceanography, Elsevier Science Publishers B.V., Amsterdam (1988) 425 p.

[34] Richard F.A. (Ed.) Coastal upwelling, American Geophysical Union, Washington D.C. (1980) 529 p.

[35] SAS Institute Inc. SAS/STAT, SAS/ETS 1989, User's Guide, Release 6.03 Edition. Cary, NC: SAS Institute Inc., 1989.

[36] Servain J., Legler D.M., Empirical orthogonal function analysis of tropical Atlantic sea surface temperature and wind stress, 1964-1979, J. Geophys. Res. 91 (1986) 14181-14191.

[37] Smith R.L., Upwelling. Oceanogr. Mar. Biol. Ann. Rev. 6 (1968) 11-46.

[38] Speth P., Detlefsen H., Meteorological influences on upwelling off Northwest Africa, Rapp. P-V. Réun. Cons. Int. Explor. Mer 180 (1982) 29-34.

[39] Speth P., Detlefsen H., Empirical orthogonal functions of sea level, pressure and sea surface temperatures for the upwelling area off Northwest Africa, Dt. Hydrogr. Z., 32 (1979) 131145 .

[40] Van Camp L., Nikjaer L., Mittelstaedt E., Schlittenhardt P. Upwelling and boundary circulation off northwest Africa as depicted by infrared and visible satellite observations, Prog. Oceanogr. 26 (1991) 357-402.

[41] Wang J.J., Walsh J.J., Objective analysis of the upwelling ecosystem off Baja Califomia, J. Mar. Res. 34 (1) (1976) 43-60.

[42] Weare B.C., Empirical orthogonal analysis of Atlantic Ocean surface temperatures, Quart. I. R. Met. Soc. 103 (1977) 467 478 .

[43] Wallace J.M., Gutzler D.S., Teleconnection in the geopotential height field during the Northern Hemisphere winter, Mon. Wea. Rev. 109 (1981) 784-812.

[44] Wolff W.J., van der Land J., Nienhuis P.H., de Wilde P.A.W.J., The functioning of the ecosystem of Banc d'Arguin Mauritania: a review, Ecological studies in the coastal waters of Mauritania, Hydrobiologia 258 (1993) 211-222.

[45] Woodruff S.D., Slutz R.J., Jenne R.L., Steuerer P.M., A Comprehensive Ocean-Atmosphere Data Set. Bull. Amer. Meteo. Society, 68 (10) (1987) 1239-1250.

[46] Wooster W.S., Bakun A., McLain D.R., The seasonal upwelling cycle along the eastern boundary of the North Atlantic, J. Mar. Res. 34 (2) (1976) 131-141. 